The Inland Waters of Tropical Africa, an introduction to tropical limnology, by L. C. Beadle. Longman, $£ 7.00$.

Fish Communities in Tropical Freshwaters, their distribution, ecology and evolution, by R. H. Lowe-McConnell. Longman, $£ 10.00$.

Considering the paucity of good books on tropical biology it is a little surprising that two, dealing with inland waters, should appear within a few months of each other and from the same publishers. But the viewpoints of the two authors differ to a large extent.

Beadle is specially interested in how the aquatic organisms of lakes, rivers and reservoirs fit into and modify the physico-chemical environment, also with the remarkable physiological adaptations of animals to extreme conditions such as the anoxic environment of tropical swamps and waters of very high temperature and salinity. From Lowe-McConnell, who has both worked in tropical America and Africa and paid visits to the Asian tropics, we have first-hand accounts of the enormous variety of fish, with species ranging from the largest freshwater fish known, Arapaima gigas of South America (now classed as a disappearing species), to tiny little species, such as certain Cichlids in Lake Malawi which live by nibbling at the individual scales of larger species. She discusses them in relation to the fish communities and the total ecosystems in which they live. Both authors discuss the extraordinary adaptive radiation of the Cichlid fishes, especially in Africa, and the Characoid fishes, especially in South America, in relation to what it can teach about the processes of evolution, so we have here two different but convergent arguments concerning such problems as the suppression of gene flow between populations, 'sympatric' and 'allopatric' speciation, and the influence of predators. Of particular interest is the fact that, especially in South America, there has been a night-time adaptation of fishes to the environment separate from the day-time adaptation - a whole community of species is dominant by day but hides away at night to be replaced by a quite different community. This could be compared with day and night communities in terrestrial and aerial communities - birds by day, bats by night which occupy ecological niches to the full. We should not forget also the give and take between the aquatic, terrestrial and aerial ecosystems, in which birds, mammals and insects play a major role.

Now that the unit of conservation is tending to change from the species to the ecosystem, without which the species can rarely survive, there is a lot in these books of direct interest to FPS members. They are certainly among the best books on tropical inland water life yet to appear.

E. B. WORTHINGTON

\title{
Looking at Animals: A Zoologist in Africa, by Dr Hugh Cott. Collins, £4.95.
}

Dr Cott sets out to whet the appetite and provide some preliminary homework for those embarking on an East African safari. Few writers have better qualifications for this task: a Cambridge don, an eminent zoologist with years of wildlife research in the Ugandan bush, a first-class photographer and a talented artist in black-andwhite; also, to give an edge to all this, a guest lecturer on many safaris with a shrewd idea of what visitors want and need to know.

$\mathrm{He}$ begins with a general introduction to the ecological setting in which the animals have their being - nothing alive exists in isolation and the web of interdependency holds each in its allotted niche. This is a theme fundamental to the proper understanding of wild places and all that live there, though it is neglected in most guide books, and Dr Cott handles it well. There follow a number of chapters which deal with some of the more interesting facts about the animals, and a few of the birds likely to be encountered. He concludes by discussing some more specialised subjects in which he himself has a particular interest: the Nile crocodile on which he 


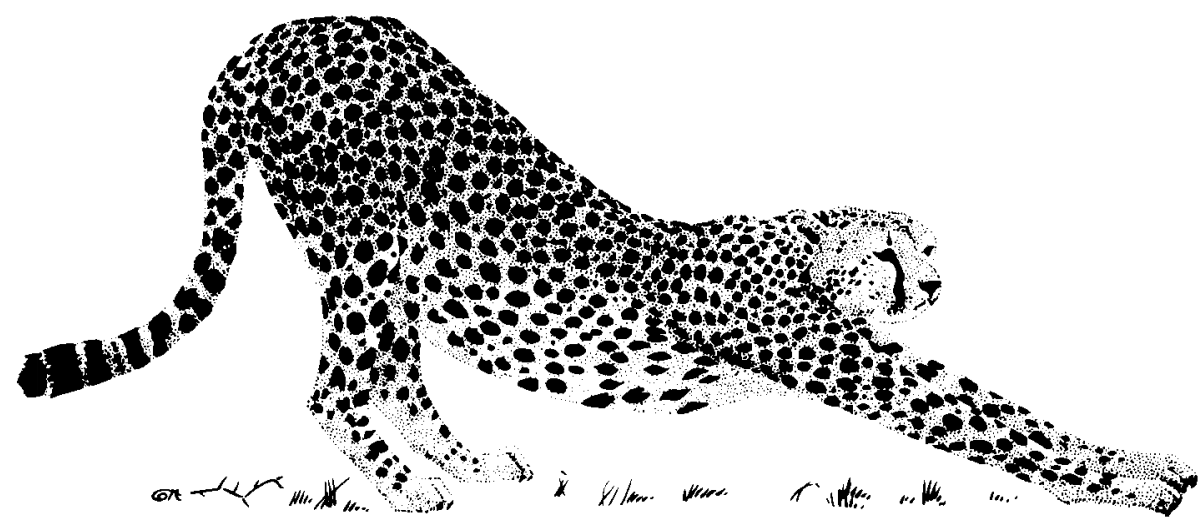

One of Dr Cott's drawings in Looking at Animals

is the world authority, coloration, the art and practice of wildlife photography and the employment of black-and-white drawing to convey the feel of Africa.

It all adds up, no doubt, to something of a rag-bag, but is none the worse for that since the contents are of fine material. Not only does he write attractively but the book is lavishly illustrated with his own work. The photography is excellent. As for his drawings, I find them wholly delightful, with an unusual felicity of design and a delicate sense of texture. The pen, guided by Dr Cott's percipient eye and finely practised hand, steals the picture from the camera every time - or so it seems to me.

Looking at Animals, unluckily, is too large for the pocket and perhaps too heavy for some suitcases. Whether packed or not, it should certainly be read before departure and it will surely come down from the shelf again on return.

JOHN OWEN

Elephants and their Habitats: the ecology of elephants in north Bunyoro, Uganda, by R. M. Laws, I. C. S. Parker and R. C. B. Johnstone. Clarendon Press, Oxford, £15.

Before Dr Laws started his work on elephants some ten years ago, very little was known about their biology. The production of this authoritative book shows how far the subject has progressed since then. The study began when it was found that the Kabalega (then Murchison) Falls National Park was overstocked with elephants and the decision was taken to reduce their numbers by culling. The controversy over elephant control need not be considered here since the authors discuss the problem fully and, considering the adverse criticisms their proposals have received, with commendable objectivity. However, their conclusions will need to be reassessed in the light of the recent increase in poaching and it is unlikely that the suggested further reduction will now be undertaken.

The scope of the book goes beyond its sub-title, for it includes some results from the authors' later work in Kenya and Tanzania. Most of the scientific data have been collected from dead elephants and cover such topics as nutrition, growth, reproduction and population dynamics. There is little on behaviour, although much of the social organisation can be deduced from the composition of the family units which were shot en bloc in order to reduce disturbance to other elephants and to prevent the breakdown of the social order.

The text is well written in an interesting style, although it makes no concessions to the 'popular' market and some passages will probably be skipped by the general reader. Similarly, the photographs are there to provide information and not to embellish the text with pretty pictures. The book will be the standard reference for 